\title{
Child Welfare Schemes in Uperwara: A hit or a flop show.
}

\author{
Ms.Eritriya Roy \\ (Economics Department, Hidayatullah National LawUniverity, Raipur, Chhatisgarh)
}

\begin{abstract}
For the development of an economy it is necessary that its human resource is educated. But a healthy mind also needs a healthy body. They being the foundational core stones of human development form an essential element of child right. Even Article 21 and 21 A of Constitution of India guarantees Right to food and free and compulsory education respectively a fundamental right of every child accentuating this reality. In recent decades, the importance of education along with proper nutrition has been reflected in increased budgetary allocations to basic education, compulsory schooling legislation, and widespread media attention to education and developmental issues This paper basically focuses upon Sarva Shiksha Abhiyan and Mid-day meal scheme, the two most prevalent welfare schemes of the Indian villages. In this paper the budgetary allocations and utilization of funds for village Uperwara towards child education and nutrition has been unveiled and their detailed analysis has been done. Its effects on child development has been analysed through secondary data. Henceforth conclusion has been drawn.

Keywords: child welfare, child rights, United Nations Convention on Rights of the Child, Article 21,Article 21A, Sarva Shiksha Abhiyan, Mid-day meal scheme, Secondary data

Research issues- Analysis of Sarva Shiksha Abhiyan and Midday Meal Scheme in Uperwara village of Chhattisgarh. .

Research Methodology- Research methodology used in this paper is analytical method.

Area and time of the study- Study was conducted in schools of Uperwara village on $9^{\text {th }}$ January, $10^{\text {th }}$ January and $11^{\text {th }}$ January, 2013
\end{abstract}

\section{Introduction}

Children constitute principle assets of any country. Children's development is very important for the overall development of society and the best way to develop national human resources is to take care of children. India has the largest child population in the world. All efforts are being made by the Government for the development and welfare of children. A number of policy initiatives have been taken for this purpose. SSA, the single largest educational initiative in the world, has created conditions for the realisation of universalisation of elementary education in the country. The Sarva Shiksha Abhiyan Mission strives to secure the right to quality basic education for all children in the 6-14 years age group. It aims at ensuring that there is significant enhancement in the learning achievement levels of children at the primary and upper primary stage. Mid-Day Meal Scheme has been launched for enhancing enrolment, retention and attendance and simultaneously improving nutritional levels among children. It has been adopted by most Indian states after a landmark direction by the Supreme Court of India on November 28, 2001. ${ }^{1}$

\section{Literature Review}

Some of the theoretical and empirical studies that contributed to the knowledge of the role of additional years of education on economic growth include Schultz (1961), Becker (1962), Mincer (1974) Acemoglu and angrist (1999), Barro (1991 and 1997), Barro and Lee (1994), Benhabib and Spiegel (1996), Hall and Jones (1999), Hanushek and Kimko (2000), Jenkins (1995), Jorgenson and Fraumeni (1992), Judson (1998), Krueger and Lindhal (1998), Moretti (1999), Murphy et al (1991), Psacharopoulos (1995) and Lewin, K M (1995). World Bank (1995) review has also documented the evidence of the effects of education on development. Duraisamy's (2000) study is perhaps one of the pioneer attempts that have looked at the returns to education in India.

\section{CHAPTER-1}

\section{CHILD RIGHTS IN INDIA}

\footnotetext{
${ }^{1}$ Court orders ,_sccommissioners.org
} 
Child Rights are fundamental freedoms and the inherent rights of all human beings below the age of $18 .^{2}$ During the $20^{\mathrm{th}}$ century with the emergence of the concept of children's' rights the idea of child welfare has undergone a significant change. Children's rights are the human rights of children with particular attention to the rights of special protection and care afforded to the young, ${ }^{3}$ including their right to association with both biological parents, human identity as well as the basic needs for food, universal state-paid education, health care and criminal laws appropriate for the age and development of the child. ${ }^{4}$

The Universal Declaration of Human Rights is seen as a basis for all international legal standards for children's rights today. There are several conventions and laws that address children's rights around the world. The United Nations' 1989 Convention on the Rights of the Child, or CRC, is the first legally binding international instrument to incorporate the full range of human rights - civil, cultural, economic, political and social rights. National governments that ratify it commit themselves to protecting and ensuring children's rights, and agree to hold themselves accountable for this commitment before the international community.

It was during the 50s decade that the UN Declaration of the Rights of the Child was adopted by the UN General Assembly. This Declaration was accepted by the Government of India. By ratifying the Convention on the Rights of the Child, the Government is obligated "to review National and State legislation and bring it in line with provisions of the Convention". The Convention revalidates the rights guaranteed to children by the Constitution of India, and is, therefore, a powerful weapon to combat forces that deny these rights. ${ }^{5}$ Various Five Year Plans, numerous programmes have been launched by the Government aimed at providing services to children in the areas of health, nutrition and education to fulfil this.

\section{CHAPTER-2}

\section{RIGHT TO EDUCATION AND CHILD WELFARE PROGRAMME}

\section{- SARVA SIKSHA ABHIYAN}

As a signatory to the United Nations Convention on Rights of the Child (UNCRC) India already recognises fundamental rights of children to Survival, Development, Protection and Participation. Article 21 (A) based on $86^{\text {th }}$ amendment of the Constitution of India states that "The State shall provide free and compulsory education to all children of the age group of six to fourteen years in such manner as the State may, by law, determine". Honouring the commitment made to the nation's children in Article 21A, THE RIGHT OF CHILDREN TO FREE AND COMPULSORY EDUICATION ACT 2009 became operational 1 st April, 2010. RTE has been a part of the directive principles of the State Policy under Article 45 of the Constitution, which is part of Chapter 4 of the Constitution. And rights in Chapter 4 are not enforceable. For the first time in the history of India this right has been made enforceable by putting it in Chapter 3 of the Constitution as Article 21. This entitles children to have the right to education enforced as a fundamental right. ${ }^{6}$ It specifies minimum norms in elementary schools and requires all private schools to reserve $25 \%$ of seats to children from poor families (to be reimbursed by the state as part of the public-private partnership plan). It also prohibits all unrecognized schools from practice, and makes provisions for no donation or capitation fees and no interview of the child or parent for admission. $^{78}$

Sarva Shiksha Abhiyan ${ }^{9}$ (SSA) under RTE the Government of India (GOI) launched Sarva Shiksha Abhiyan (SSA) as its flagship program in 2001-02, covering the entire elementary cycle and applied to all districts of the country in a mission mode, as mandated by the 86th amendment to the Constitution of India making free education to children aged 6-14, a fundamental right. SSA is being implemented in partnership with State Governments to cover the entire country. The programme aims at opening new schools in those habitations without schooling facilities and to strengthen existing school infrastructure through provision of additional class rooms, toilets, drinking water, maintenance grant and school improvement grants. Existing schools with

\footnotetext{
${ }^{2}$ CRY,http://www.cry.org/crycampaign/ChildRights.htm(last accessed on Feb. 1,2013 )

${ }^{3}$ Children's Rights, http://www.amnestyusa.org/our-work/issues/children-s-rights/the-right-to-education (Last accessed on Feb. 1,2013)

${ }^{4}$ Convention on the Rights of the Child, http://www2.ohchr.org/english/law/crc.htm (Last accessed on Jan. 31,2013)

${ }^{5}$ Child Rights in India, http://www.unicef.org/india/children_3220.htm (Last accessed on Jan. 31,2013)
}

6 Right To Education (RTE) Act,2009 Right of children to Free and Compulsory Education Act, http://www.icbse.com/right-to-education-act (Last accessed Feb 1,2013).

7 Cabinet clears long-pending Education Bill, THE HINDU (New Delhi), November 1, 2008.

8 Sripati, V. \& Thiruvengadam, India: Constitutional amendment making the right to education a Fundamental Right, INTERNATIONAL JOURNAL OF CONSTITUTIONAL LAW 2, 148.

${ }^{9}$ Hereinafter referred as SSA 
inadequate teacher strength are provided with additional teachers, and the capacity of existing teachers is being strengthened by extensive training, grants for developing teaching-learning materials and strengthening of the academic support structure at a cluster, block and district level. SSA seeks to provide quality elementary education including life skills. SSA has a special focus on female education and children with special needs. SSA also seeks to provide computer education to bridge the digital divide. It aims provide quality elementary education including life skills with a special focus on the education of girls and of children with special needs, as well as computer education. ${ }^{10}$

\section{CHAPTER-3}

\section{RIGHT TO FOOD \& NUTRITION AND WELFARE PROFRAMME}

\section{- MID-DAY MEAL PROGRAMME}

Human body requires a mix blend of proteins, vitamins, minerals, and fatty acids in an appropriate ratio to ensure proper and smooth functioning of all the human systems. If this requirement is not met, the person suffers from variety of diseases and ill health. ${ }^{11}$

The right of the child to survival, to health, to nutrition and to food have emerged as aims and a measure of progress, for children. Universal Declaration of Human Rights (1949) recognizes this by providing right to adequate nutrition. Article 11 of the International Covenant on Economic, Social and Cultural Rights (1966) and the General Comment 12 of the Committee on Economic, Social and Cultural Rights further elaborate the responsibilities of all State Parties to recognize the right of everyone to be free from hunger. Further responsibilities in this regard, particularly with reference to children and women, derive from the Convention of the Rights of the Child (Articles 27.1 and 27.3) and the Convention on the Elimination of All Forms of Discrimination against Women (Article 12). India is a signatory to the Universal Declaration of Human Rights, the International Covenant on Economic, Social and Cultural Rights and the Convention on the Rights of the Child.

Further, Article 21 of the Constitution of India guarantees a fundamental right to life which includes the right to health and its determining factors, including food. Article 39 (a) of the Constitution of India obliges the State to direct its policy towards ensuring that the citizens, men and women, equally, have the right to an adequate means of livelihood. Article 47 of the Constitution of India makes it one of the primary duties of the State to raise the standard of nutrition and the standard of living of its people and to improve public health. ${ }^{12}$

The Mid day Meal Scheme ${ }^{13}$ is the popular name for school meal programme in India which started in the 1960s. It involves provision of lunch free of working days. The key objectives of the programme are: protecting children from classroom hunger, increasing school enrolment and attendance, improved socialization among children belonging to all castes, addressing malnutrition, and social empowerment through provision of employment to women. With a view to enhancing enrolment, retention and attendance and simultaneously improving nutritional levels among children, the National Programme of Nutritional Support to Primary Education (NP-NSPE) was launched as a Centrally Sponsored Scheme on 15th August 1995, initially in 2408 blocks in the country. Central Assistance under the scheme consisted of free supply of food grains @ 100 grams per child per school day, and subsidy for transportation of food grains up to a maximum of Rs 50 per quintal. In September 2004 the scheme was revised to provide cooked mid day meal with 300 calories and 8-12 grams of protein to all children studying in classes I - VIII in Government and aided schools and EGS/ AIE centres.

Table 1: Budgetary Allocation under MDM scheme

\begin{tabular}{|l|l|}
\hline Year & Budget(in cr) \\
\hline $2008-09$ & 8000 \\
\hline $2009-10$ & 8000 \\
\hline $2010-11$ & 9440 \\
\hline $2011-12$ & 10380 \\
\hline $2012-13$ & 11,937 \\
\hline
\end{tabular}

To decrease gaps in several areas, including supply of food grains, cooking, and supervision and monitoring, and teaching time, which is diverted towards supervision in schools where food is prepared on the premises the Planning commission recommended for inviting Public Private Partnerships (PPPs) for implementing mid-day

\footnotetext{
${ }^{10}$ Sarva Shiksha Abhiyan, http://ssa.nic.in/ (Last accessed on Feb. 2,2013).

${ }^{11}$ Indian Women and Nutrition, http://www.indianchild.com/womensissues/indian-women-and-nutrition.htm (Last accessed on Feb. 2,2013)

${ }^{12}$ Right To Food, http://www.navdanya.org/campaigns/right-to-food (Last accessed on Feb. 2,2013)

${ }^{13}$ Hereinafter referred as MDM.
} 
meal scheme. Today PPP model in MDM programme has led to improvement in efficiency, accountability and effective service delivery. ${ }^{14}$

\section{CHAPTER-4}

\section{CHHATTISGARH: An Insight}

With a rich past and soaked amidst its mythical aura, Chhattisgarh is a young state acquiring 135,00 square kilometer ${ }^{15}$. Located in the heart of India, it shares its borders with six States of the country; Uttar Pradesh to the north, Jharkhand to the north-east, Orissa to the east, Madhya Pradesh to the west and north-west, Maharashtra to the south-west and Andhra Pradesh to the south-east ${ }^{16}$, and is a land of opportunities ${ }^{17}$. Popularly known as the 'Rice bowl' of India, it is the twenty seventh state of the country. With twenty seven districts at present, it has a Human Development Index value of $0.358^{18}$.Chhattisgarh has a low standard of living which can be shown as per the income index which is equal to 0.127 . Chhattisgarh has a good level of literacy also. Compared to its neighbouring States, Chhattisgarh reports a better education index of $0.526^{19}$ though it is lower than the national average of 0.536 . Health index of Chhattisgarh is less than $0.49^{20}$ and this is due to the low level of health condition and health facilities in remote areas of the State. Raipur, the capital city has become an educational hub for the students and is the main centre of higher education. According to 2011 census, the sex ratio of the State is 991 (per 1000 males) and density of population is 189 persons per square kilometre.

As per 2011 census, $71.04 \%$ of the population can read and write in atleast one language amongst which $81.45 \%$ are males and $60.51 \%$ are females ${ }^{21}$. The education scenario in Chhattisgarh is not very remarkable as it lacks proper educational infrastructure. However, the state government has launched programs such as Kasturba Gandhi Balika Vidyalayas(KGBVs), National Programme for Elementary Education of Girls at elementary Level (NPEGEL), Sarva Shiksha Abhiyan, Rashtriya Madhyamik Shiksha Adhiniyam for enhancing the academic scenario of the state. There are basically two Education schemes namely Sarva Shiksha Abhiyan and Rashtriya Madhyamik Shiksha Adhiniyam that are run by the Chhattisgarh Government in their jurisdiction. KEY DATA: Elementary Education (2008-09) 22

\begin{tabular}{|c|c|c|c|c|c|c|c|c|}
\hline Particulars & $\begin{array}{l}\text { Total } \\
\text { Schools }\end{array}$ & & $\begin{array}{l}\text { Rural } \\
\text { Schools }\end{array}$ & & $\begin{array}{l}\text { Total } \\
\text { Enrolment }\end{array}$ & & $\begin{array}{l}\text { Rural } \\
\text { Enrolment }\end{array}$ & \\
\hline & Govt. & Private & Govt & Private & Govt. & Private & Govt & Private \\
\hline $\begin{array}{l}\text { Primary } \\
\text { only }\end{array}$ & 3081 & 219 & 2836 & 151 & 410,924 & 22,233 & 352,475 & 12,496 \\
\hline $\begin{array}{l}\text { Primary } \\
\text { with Upper } \\
\text { Primary }\end{array}$ & 20 & 344 & 17 & 144 & 2,243 & 98,886 & 1,980 & 32,823 \\
\hline $\begin{array}{l}\text { Primary } \\
\text { with Upper } \\
\text { Primary } \\
\text { Sec/Higher } \\
\text { Sec }\end{array}$ & - & - & - & - & - & - & - & - \\
\hline $\begin{array}{l}\text { Upper } \\
\text { Primary } \\
\text { only }\end{array}$ & 1,552 & 31 & 1,427 & 20 & 165,031 & 4350 & 141549 & 1942 \\
\hline
\end{tabular}

${ }^{14}$ BHARATHI GHANSHYAM, PPPs and centralized kitchen: A boon for the MDM programme, Yojana 54 ( Nov, 2012)

${ }^{15}$ Human Development Report: Chhattisgarh, PLANNING COMMISSION OF INDIA, 9 (June 26, 2005), http://planningcommission.nic.in/plans/stateplan/sdr_pdf/shdr_chh05.pdf.

${ }^{16}$ Ibid.

${ }^{17}$ Profile, CHHATTISGARH GOVERNMENT, http://cg.gov.in/profilenew/profile1.htm (last accessed on 28th Jan,2013).

${ }^{18}$ Chhattisgarh Economic And Human Development Indicators, UNDP ,2 (last accessed on 28th Jan,2013 )

http://www.undp.org/content/dam/india/docs/chhattisgarh_factsheet.pdf.

${ }_{19}$ India Human Development Report 2011, INSTITUTE OF APPLIED MANPOWER RESEARCH, 25 (2011), http://www.pratirodh.com/pdf/human_development_report2011.pdf.

${ }^{20}$ Ibid at pg 27.

${ }^{21}$ Provisional Population Totals - India - Data Sheet Based On Census 2011, CENSUS OF INDIA, 243 (Dec

5,2012 ) http://planningcommission.nic.in/data/datatable/0512/databook_242.pdf

${ }^{22} 1$ DISTRICT ELEMENTARY EDUCATION REPORT CARD 2008-09,117 ( $1^{\text {st }}$. ed, 2011) 


\begin{tabular}{|l|l|l|l|l|l|l|l|l|}
\hline $\begin{array}{l}\text { Upper } \\
\text { Primary } \\
\text { with } \\
\text { Sec./Higher } \\
\text { Secondary }\end{array}$ & - & - & - & - & - & - & - & - \\
\hline $\begin{array}{l}\text { No } \\
\text { response in } \\
\text { school } \\
\text { category }\end{array}$ & - & - & - & - & - & - & - & \\
\hline
\end{tabular}

\begin{tabular}{|l|l|l|}
\hline SC,ST \& OBC Enrolment & Primary & Upper Primary \\
\hline \% SC enrolment & 21.1 & 19.2 \\
\hline \%SC girls to SC enrolment & 49.0 & 48.8 \\
\hline \%ST enrolment & 14.2 & 12.8 \\
\hline \%ST girls to ST enrolment & 49.0 & 47.8 \\
\hline \%OBC enrolment & 58.7 & 60.7 \\
\hline $\begin{array}{l}\text { \%OBC girls to OBC } \\
\text { enrolment }\end{array}$ & 49.0 & 49.8 \\
\hline
\end{tabular}

KEY DATA: Elementary Education (2009-10) $)^{23}$

\begin{tabular}{|l|l|l|l|l|l|l|l|l|}
\hline & $\begin{array}{l}\text { Total } \\
\text { Schools }\end{array}$ & & $\begin{array}{l}\text { Rural } \\
\text { Schools }\end{array}$ & & $\begin{array}{l}\text { Total } \\
\text { Enrolment }\end{array}$ & & $\begin{array}{l}\text { Rural } \\
\text { Enrolment }\end{array}$ & \\
\hline & Govt. & Private & Govt & Private & Govt. & Private & Govt & Private \\
\hline Primary only & 3072 & 207 & 2797 & 137 & 385,676 & 16,315 & 331,015 & 10,337 \\
\hline $\begin{array}{l}\text { Primary with } \\
\text { Upper Primary }\end{array}$ & 66 & 318 & 57 & 134 & 7448 & 64759 & 6622 & 22837 \\
\hline $\begin{array}{l}\text { Primary with } \\
\text { Upper Primary } \\
\text { Sec/Higher Sec }\end{array}$ & 18 & 136 & 8 & 32 & 5918 & 38,801 & 1577 & 7976 \\
\hline $\begin{array}{l}\text { Upper Primary } \\
\text { only }\end{array}$ & 1,413 & 19 & 1,296 & 16 & 150739 & 2148 & 126782 & 1179 \\
\hline $\begin{array}{l}\text { Upper Primary } \\
\text { with } \\
\text { Sec./Higher } \\
\text { Secondary }\end{array}$ & 116 & 14 & 96 & 4 & 22035 & 1938 & 17333 & 561 \\
\hline $\begin{array}{l}\text { No response in } \\
\text { school category }\end{array}$ & 16 & - & - & - & - & - & - & - \\
\hline
\end{tabular}

\begin{tabular}{|l|l|l|}
\hline SC,ST \& OBC Enrolment & Primary & Upper Primary \\
\hline \% SC enrolment & 21.3 & 19.6 \\
\hline \%SC girls to SC enrolment & 49.4 & 49.1 \\
\hline \%ST enrolment & 14.0 & 12.4 \\
\hline \%ST girls to ST enrolment & 49.4 & 48.8 \\
\hline \%OBC enrolment & 58.2 & 60.7 \\
\hline $\begin{array}{l}\text { \%OBC girls to OBC } \\
\text { enrolment }\end{array}$ & 48.7 & 49.7 \\
\hline
\end{tabular}

Even the Constitution of India envisages the establishment of a new social order based on equality, freedom, justice and the dignity of the individual. It aims at the elimination of poverty, ignorance and ill-health and directs the State to regard the raising of the level of nutrition and the standard of living of its people and the improvement of public health as among its primary duties, securing the health and strength of workers, men and women, specially ensuring that children are given opportunities and facilities to develop in a healthy manner.

${ }^{23} 1$ DISTRICT ELEMENTARY EDUCATION REPORT CARD 2008-09,117 ( $\left(1^{\text {st }}\right.$ ed, 2011) 
- Uperwara lying in Abhanpur block of Raipur district is one of the twenty-eight villages present in Abhanpur. With a population of 3893, Uperwara has four Government schools; two primary, one high school, one higher secondary school, all of which are fully functional. Despite their primary occupation being agriculture and a majority of people barely crossing the Below Poverty line, the population here is quite vigilant about the schemes running for school children.

The analysis of the schemes SSA and MDM has been done for two primary and one high school falling in the area of research.

\section{CHAPTER-5}

\section{BUDGET EXPENDITURE AND ITS PERFORMANCE FOR SSA FOR RAIPUR DISTRICT}

A budget is a financial document which shows an estimation of revenue and expenditure for a given project or scheme for a specified period. The budget process is carried out to have a raw idea of receipts which will be earned and expenditure and the outlays will be incurred while performing the functions to achieve the given targets of a project or scheme.

The reference period for this paper is taken as 2 years and the expenditure under the project is shown for the year 2011-12 and the proposed outlay of 2012-13 for Raipur district. In the year 2012-13 two more schools were opened under SSA in Raipur district. The total financial outlay for special training for mainstreaming of Out-of-School children for the year 2011-12 is recorded as 1483 Lakh Rupees while in the year 2012-13 the proposed outlay has been recorded as 710.27 Lakh Rupees. The expenditure list includes residential and non-residential facilities for continuous twelve months, seasonal hostels for migrants, dormitory for tribal students.

While there has been increase in the Outlay for Teaching Learning equipment for the year 2012-13.For achieving the Retention objective under SSA which includes Primary only, Upper Primary and Higher Secondary Section, the total expenditure for free textbooks which includes free textbooks, Brail books and Large print books was Rs.987.11 lakhs for the year 2011-12 but the achievement was only of Rs.773.67 lakhs which is only seventy-eight percent of the outlay. The remaining part i.e. Rs 213.44 lakh was taken as saving for carried forward in the year 2012-13 and the Outlay which was proposed for free textbooks for the year 2012-13 was 290.45 lakhs. This shows a decrease in total outlay for free textbook under SSA. The outlay for workbooks for Primary and Upper Primary section proposed for the year 2012-13 is 30.95 Lakhs. The expenditure for providing two sets of uniform to children studying in Government schools in the year 2011-12 was Rs.1512.064 Lakh. There was $100 \%$ utilisation of the Funds in that reference period while a decrease in outlay for the year 2011-12 has been recorded as the outlay stands at Rs.557.46 Lakh. The beneficiaries include all girls, SC and ST boys and Below Poverty line boys.

Infrastructure is a permanent framework which supports economy's other production works (Building Responsible Competitiveness). Infrastructure links people to services. Thus investment in infrastructure plays a very important role in completion and achievement of the targets of the project. The cost of civil work expenditure for the year 2011-12 under SSA was recorded as Rs.10513.165 Lakhs. But there was only 35\% achievement and Rs.6850.67 LAkhs was counted as savings. In the year 2012-13 the outlay for the same head is Rs.7165.10 Lakhs (proposed). The saving for the previous year has been carried forward which results in increase in total outlay under civil works. Civil works includes repairing of building structure, outlay for primary and upper primary schools, Construction of boys 'toilets and urinals, separate girls toilets, drinking water facilities, construction of boundary wall and separation wall, electrification, augmentations of training facilities, construction of special residential schools, construction of ramps , furniture for Government upper primary section and major repair work for primary schools. The analysis shows that under some heads there has been proper utilisation of the resources while under some underutilisation of financial resources has been recorded.

\section{CHAPTER-6}

\section{BUDGETARY ALLOCATION FOR SCHOOLS UNDER SARVA SIKSHA ABHIYAN IN UPERWARA}

A primary school under SSA was opened in the year 1952. Total number of students for the year 2012 is 115.In fifth standard the total number of students was recorded as 42. And a major positive result of SSA is the drop out is zero. In the year 2011-2012 the amount sanctioned under SSA is divided in following categories:-

Teaching Learning Material (TLM) - Rs 3000

Study material - Rs 5000

Maintenance- Rs 7500

A steep increase in the sanctioned amount has been noted for the year 2012-13 for the school under SSA. The school received a total amount of Rs 54800. For the first time amount for School Uniform and Continuous Comprehensive Evaluation (CCE) was sanctioned for the school. For school uniform the school 
received Rs 25200 while Rs 11600 has been sanctioned for CCE. The amount for teaching learning material remained the same while there has been decrease in the amount sanctioned for Maintenance by Rs 2500 . A partial success of SSA can be figured out by the increase in the amount sanctioned for study material. The amount which the school received in the year 2012-2013 for study material is Rs 10000 .

2. Another primary school (class 1-5) which was started in the year 1997 under SSA has the total enrolment of 124 students (59 boys and 65 girls). Total number of students enrolled for class 5th for the year 2012-2013 is 27 (11 boys and 16 girls). The dropout rate has been analyzed as zero.

In the year 2012-2013, the total amount sanctioned and released for the school under the scheme is Rs 57800. For Teaching Learning Material (TLM) the school received the total amount of Rs 2000. An amount of Rs 5000 has been received by the school in the form of grants. The amount issued for the purpose of maintenance of the school is Rs 10000. For CCE a total amount of Rs 12800 has been received by the school under SSA. In the year 2012-13, for the first time for distribution of free school uniforms, the school received a grant of Rs 28800. 72 students were recorded as beneficiaries. The beneficiaries include 60 girls of OBC, 06 boys of ST population and 06 boys of BPL. Each of the beneficiaries is entitled to get 2 sets of uniform.

3. In 1965 an Upper Primary School (class 6-8) was started by the education department under SSA. The total number of students enrolled in the school is recorded as 319 . Total number of students enrolled in class 8th for the year 2012-13 has been recorded as 116. While in the year 2011-12 there were 85 students enrolled in the same class.

The school has total six teachers and the amount received for TLM is Rs 500 per teacher. In 2012-13 Rs 10000 has been sanctioned for the maintenance while in 2011-12 the amount for the same purpose was Rs 7500. For study material Rs 7000 has been released under SSA for the school. The total amount received by the school for distributing free school uniform is Rs 77000 and the number of beneficiaries for the year 2012-13 is 194.

\section{CHAPTER-7}

\section{POSITION OF SCHOOLS OPERATING MID DAY MEAL SCHEME IN UPERWARA}

MDM scheme for Primary school with total student strength of 115 students is carried out in the following manner:

The school employs two workers (cooks) under the scheme and the workers receive Rs.1000 each on monthly basis.

Under this scheme each student of the school is entitled to get 100 gram rice each day. In addition to that the expenditure for per child under this scheme is Rs.3.68. Prior to Oct,2012 the expenditure for per student under the scheme was Rs.3.40

The total expenditure of the school under MDM for the month varies on the basis of the number of beneficiaries of the scheme per day.

In December, 2012 the school met an expenditure of Rs.7,500 under the scheme. In October, 2012 the total expenditure stood as Rs.6,470. In the month of July, 2012 the total expenditure incurred by the school under MDM was Rs9,618.

MDM scheme under another Primary school runs in a similar way.

The total expenditure for the month of Dec,2012 has been recorded as Rs.7,812, while in October,2012 the school incurred the expenditure of Rs7000 for the scheme. In the month of July, the expenditure in MDM per day per student was Rs.3.40 and the total expenditure on it was recorded as Rs.9670.

The Upper Primary school which was opened in the year 1965 also runs MDM scheme for the nutritional benefit of the students enrolled.

In this section per child receives 150 gram of rice. The total monthly expenditure for the workers (cook) under the scheme is Rs.2000. In addition to 150 grams of rice each beneficiary is entitled to receive per day an amount Rs.4.70 under the scheme. This amount has been increased in the year 2012-13 whereas in 2011-12 the amount for the beneficiaries (per day) was recorded as Rs.4.40. In December,2012 in addition to 100 grams rice to per student, the total expenditure incurred by the school was Rs.11,303. In October, 2012 the expenditure incurred by the school has been recorded as Rs11,801 while in July,2012 the total expenditure at a rate of Rs.4.40 per student was recorded as Rs.16,297.

\section{CHAPTER-8}

\section{FINDINGS AND CONCLUSION}

The district outlay pattern of both the schemes shows that the funds allocated for the schemes were not fully utilised. The achievement level under different heads varied from $35 \%$ to $78 \%$. This reflects the improper functioning of the schemes. But a partial success can also be credited to the increase in the number of schools in Raipur district. Looking towards the success of SSA for village Uperwara, the drop out level of the student is zero. This is due to the successful function of MDM scheme in all the three schools of the village. Another 
reason which can be figured out is proper awareness of the scheme among the individuals through legal awareness programmes organised by Samanway which is a legal aid society of Hidayatullah National Law University, Raipur. An increase in enrolment rate in the schools shows the success of SSA and MDM in the village. It has been analysed that there is zero drop out till class $8^{\text {th }}$ but a steep decrease in enrolment and increase in the dropout has been found out after standard $8^{\text {th }}$. This shows that both the schemes work effectively and efficiently only till standard $8^{\text {th }}$. After upper primary level, both the schemes fail to work because of the existence of poverty. The students get lured to attend school till Class 8 in the name of free food which is provided through MDM. As they do not remain the beneficiary of MDM scheme after Class 8 , they include themselves in the drop-out population.

The success of both the schemes is conditional on the degree of precision and detail in its implementation. It means that every rupee allocated has to be spent just right. every provision entailed in the act has to be thoroughly accounted for, and budgetary allocation must be made accordingly. If the government is serious about achieving UEE in India, financial constraints can no longer be used as an excuse. A grey shade picture can be drawn for the outcome of both the schemes running in village Uperwara. In certain aspects, the schemes presents a good image while in other the schemes fails to achieve the target of universalisation of education.

\section{Refernces}

[1] IMF (2008). World Economic Outlook Database. (Washington, DC, International Monetary Fund, April 2008).

[2] UNDP, 2010-2011, Human Development Report (New York, United Nations Development Programme) http://hdr.undp.org.

[3] Census of India 2001\&2011(http://www.censusindia.net/results/)

[4] Government of India, Ministry of Rural Development http://rural.nic.in/book01-02/ch-2.pdf. See also http://rural.nic.in/book00-01/ch2.pdf.

[5] Government of India. Child Development. Ministry of Human Resource Development, Department of Women and Child Development (http://wcd.nic.in/)

[6] Chandrasekhar S. and Abhiroop Mukhopadhyay. 2006, September. "Primary Education as a Fundamental Right, Cost Implications". Economic and Political Weekly. 41 (35): 3797-3804.

[7] India, Gazette of. 2009. The Right of Children to Free and Compulsory Education Act, 2009. Government Report, New Delhi: Government of India Press.

[8] Mukherjee, Anit N. and Tapas K. Sen. 2007. Universalising Elementary Education: An Assessment of the Role of the Sarva Shiksha Abhiyan. National Institute of Public Finance and Policy.

[9] Baru, Rama et al (2008): Full Meal or Package Deal?, Economic and Political Weekly, 14 June

[10] Parikh, Kalpana and Yasmeen, Summiya (2004): Groundswell for mid-day meal scheme, India Together.

[11] Ravi, Padmalatha (2006): School meals make slow progress, India Together.

[12] Zaidi, Annie (2005): Food for education, Volume 22 - Issue 05, Feb. 26 - Mar. 11, Frontline. 